\title{
Krüppel-Like Factor 4 (KLF4) Is Not Required for Retinal Cell Differentiation ${ }^{1,2,3}$
}

\author{
Jiahua Fang, ${ }^{1,2, *}$ - Peter X. Shaw, ${ }^{1, *}$ Yan Wang, ${ }^{1}$ and ${ }^{-}$Jeffrey L. Goldberg ${ }^{1,3}$
}

DOI:http://dx.doi.org/10.1523/ENEURO.0117-15.2016

${ }^{1}$ Department of Ophthalmology and Shiley Eye Institute, University of California San Diego, La Jolla, California 92093, ${ }^{2}$ Department of Ophthalmology, Changsha First People's Hospital, Changsha 410008, Hunan, China, and ${ }^{3}$ Byers Eye Institute at Stanford, Palo Alto, California 94303

\begin{abstract}
During early vertebrate eye development, a regulatory network of transcription factors regulates retinal cell differentiation and survival into adulthood. Among those factors, Krüppel-like factor 4 (KLF4) plays the dual role of maintaining the stem cell status of retinal progenitors cells and repressing the intrinsic axon regeneration ability in retinal ganglion cells (RGCs) after injury. This study further investigated whether KLF4 plays a role in early retinal cell differentiation or survival into adulthood. We examined different types of retinal neurons, including RGCs, amacrine cells, bipolar cells, Müller cells, and photoreceptor cells, in adult mice in which KLF4 was conditionally deleted in early retinal development using Chx10-promoted Cre by immunohistochemistry. We compared the numbers of retinal neurons and the thickness of photoreceptor and nerve fiber layers between Chx10-Cre-driven KLF4 deletion mice and wild-type mice. There was no significant difference in cell number among any of the retinal cell types or in photoreceptor layer thickness with KLF4 deletion during early development. The thickness of axon bundles in the nerve fiber layer in the Chx 10 conditional KLF4 knock-out mice was greater than that in wild-type mice. These results suggest that KLF4 is not required for retinal cell differentiation or survival, but does normally limit retinal ganglion cell axon bundle thickness. These data support a hypothesis that KLF4 suppresses axon growth during development.
\end{abstract}

Key words: axon growth; Krüppel-like factor 4; retinal development; retinal ganglion cells

\section{Significance Statement}

Although it has been well studied for its role in reprogramming somatic cells into induced pluripotent stem cells and the repression of axon regeneration of optic nerve injury, whether Krüppel-like factor 4 (KLF4) plays any role in retinal neuronal differentiation and survival into adulthood is still poorly understood. This study provides a line of evidence that the absence of KLF4 in early development does not affect retinal neuron differentiation into designated cell types.

\section{Introduction}

The neural retina comprises six types of neurons (retinal ganglion cells, amacrine, horizontal, bipolar, and rod and cone photoreceptors) and one type of glial cell (Müller cell). They are generated from a common pool of multi-

Received September 29, 2015; accepted January 5, 2016; First published January 13, 2016

${ }^{1}$ J.L.G. is a coinventor on a patent relating to Krüppel-Like Factor 4 in axon regeneration. The authors declare no other competing financial interests.

${ }^{2}$ Author contributions: J.F., P.X.S., and Y.W. performed research; J.F., P.X.S., and J.L.G. analyzed data; J.F., P.X.S., and J.L.G. wrote the paper; P.X.S. and J.L.G. designed research. potent retinal progenitor cells (RPCs). During vertebrate retina development, the differentiation of retinal cells occurs in a defined order (Cepko et al., 1996; Livesey and Cepko, 2001; Turner and Cepko, 1987). Retinal ganglion cells (RGCs) are generated first along with cone photoreceptors, amacrine cells, and horizontal cells, followed by bipolar neurons and rod photoreceptors, and ending

\footnotetext{
${ }^{3}$ This research was supported by National Institutes of Health/National Eye Institute Grants R01-EY-020913, R01-EY-025693, and P30-EY-022589; an unrestricted grant from Research to Prevent Blindness; and a Visiting Scholar Grant from President Li Mengxiong and the First Hospital of Jingzhou to J.F. *J.F. and P.X.S. contribute equally to this work.
} 
with Müller glia, with considerable overlap among these phases (Cepko, 1999; Livesey and Cepko, 2001). In the early stages of retinal development, RPCs generate these different cell types under the regulation of a combination of extrinsic and intrinsic influences (Livesey and Cepko, 2001). The ability of RPCs to generate particular progeny is specified by transcription factors that define their competence to differentiate into single or perhaps subsets of retinal cell types (Cepko, 1999). Transcription factors known to regulate these functions include members of the basic helix-loop-helix (Hatakeyama and Kageyama, 2004; Yao et al., 2010), homeodomain (Dorval et al., 2005), and forkhead families (Moose et al., 2009).

Krüppel-like factors (KLFs) are a subfamily of evolutionarily conserved zinc finger DNA-binding transcription factors (Bieker, 2001; Ghaleb et al., 2005). Seventeen mammalian KLFs have been identified, all of which have three highly conserved zinc finger motifs at the $C$ terminus; bind to similar consensus GT-box or CACCC DNA response elements; and function as transcriptional activators, repressors, or both (Dang et al., 2000; Moore et al., 2011; Turner and Crossley, 1999). These factors regulate various biological functions in development and adulthood, including cell growth, apoptosis, proliferation, and differentiation (McConnell and Yang, 2010). Different KLFs have been linked to the differentiation of different cell types, for example, KLF1 in erythropoiesis (Drissen et al., 2005), KLF2 in thymocytes (Carlson et al., 2006), KLF7 in olfactory sensory neurons (Kajimura et al., 2007), and KLF4 in monocytes (Alder et al., 2008) and corneal epithelial cells (Swamynathan et al., 2007).

KLF4 is expressed during murine eye development (Chiambaretta et al., 2004). When the KLF4 gene was selectively deleted in the surface ectoderm-derived structures of the eye with Pax6-driven Cre (le-Cre mice), 8-week-old mice exhibited multiple ocular defects, including corneal epithelial fragility, stromal edema, defective lens, and loss of conjunctival goblet cells (Swamynathan et al., 2007). We previously reported that KLF4 is developmentally regulated in RGCs and suppresses their intrinsic capacity for rapid axon growth (Moore et al., 2009). In that article, we did not see a defect in RGC numbers in adult mice after deleting KLF4 with a thy-1-promoted Cre in early development, but whether KLF4 regulates retinal neurons, including RGC differentiation, when deleted at the beginning of retinal development before Thy 1 expression is turned on in postmitotic RGCs, remains to be determined. In this report, we created early retinal KLF4 conditional knock-out mice by breeding Chx10-Cre Tg with $\mathrm{KLF}^{\mathrm{fl} / \mathrm{fl}}$ mice. Using immunohistochemical methods, we examined retinal architecture compared with agematched wild-type (WT) controls.

Correspondence should be addressed to Dr. Jeffrey L. Goldberg, Byers Eye Institute at Stanford, 2452 Watson Court, Palo Alto, CA 94303. E-mail: jlgoldbe@stanford.edu.

DOI:http://dx.doi.org/10.1523/ENEURO.0117-15.2016

Copyright (C) 2016 Fang et al.

This is an open-access article distributed under the terms of the Creative Commons Attribution 4.0 International, which permits unrestricted use, distribution and reproduction in any medium provided that the original work is properly attributed.

\section{Materials and Methods}

\section{Animals}

All procedures involving animals were in accordance with the ARVO Statement for the Use of Animals in Ophthalmic and Vision Research and were approved by the Institutional Biosafety Committee and the Institutional Animal Care and Use Committee at the University of California, San Diego. Conditional knock-out mice were generated by breeding KLF4-floxed mice (Moore et al., 2009) and Chx10-Cre mice (Jax mice stock \#005105, The Jackson Laboratory); genotyping was confirmed by PCR, as in our prior publication (Moore et al., 2009). Age-matched littermates without the Chx10-cre allele served as controls. For counting and statistical analysis of adult retinas, a minimum of three mice of either sex were included in each group.

\section{Western blot}

Adult mice of indicated genotypes were killed, and retinas were dissected and lysed with lysis buffer (Cell Signaling Technology) containing $0.5 \mathrm{~mm}$ phenylmethylsulfonyl fluoride (Sigma-Aldrich). Protein concentration was determined by BCA protein assay (Thermo Fisher Scientific). Samples $(25 \mu \mathrm{g})$ were separated by SDS-PAGE in $4-20 \%$ gradient Tris-glycine precast gels (Invitrogen) and transferred to a polyvinylidene difluoride membrane (Millipore). The membrane was incubated for $1 \mathrm{~h}$ in blocking solution containing $5 \%$ nonfat milk powder and $0.1 \%$ Tween-20, $\mathrm{pH} 7.6$. This was followed by overnight incubation at $4^{\circ} \mathrm{C}$ in the blocking buffer containing rabbit primary antibodies against KLF4 (1:50; Ab72543, Abcam). Subsequently, the labeled proteins were visualized by incubation with a horseradish peroxidase (HRP)-conjugated anti-goat or rabbit IgG (1:2000; Santa Cruz Biotechnology) followed by development with a chemiluminescence substrate for HRP (Thermo Fisher Scientific). The images of Western blots were captured by GE ImageQuant. Relative band intensities were analyzed using ImageJ software and normalized to GAPDH.

\section{Immunohistochemistry}

Animals under deep anesthesia underwent cardiac perfusion with $4 \%$ paraformaldehyde. Whole adult eyes were isolated, the corneas were incised to facilitate intraocular fixative penetration, and the eyeballs were transferred to PBS containing 4\% paraformaldehyde for $1 \mathrm{~h}$ at room temperature, followed by $10 \%$ sucrose in PBS and, finally, $30 \%$ sucrose in PBS. Eyes were then mounted in optimal cutting temperature compound (Sakura Finetek USA), frozen, and cryosectioned at $5 \mu \mathrm{m}$ thickness. At least three sections with an interval of $50 \mu \mathrm{m}$ were acquired from each eye across the optic nerve to ensure retinal centration, for a total of 18 sections in each group. Cryosections were rinsed with PBS and blocked with $5 \%$ goat serum albumin (Thermo Fisher Scientific) and 0.2\% Triton X-100 (Sigma-Aldrich) in antibody buffer for $1 \mathrm{~h}$. Tissue was then incubated in antibody buffer containing primary antibody for $24 \mathrm{~h}$ at $4^{\circ} \mathrm{C}$. The following antibodies were used: for RGCs, mouse anti-Brn3a (1:100; MAB 1585, EMD Millipore); for RGC axons, mouse monoclonal $\beta$ Ill-tubulin (1:100; Tuj1, Convance); for amacrine cells, mouse monoclonal anti-Pax6 (1:100; sc-81649, Santa Cruz Biotech- 
A

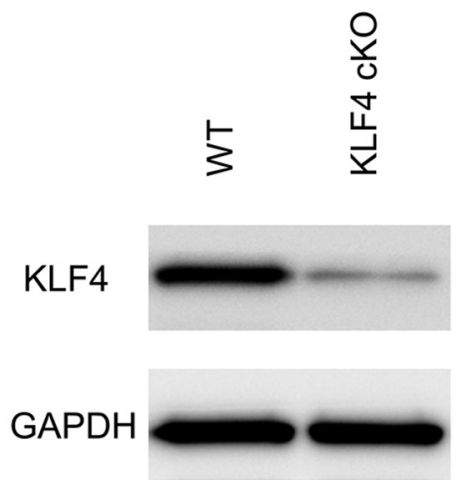

B

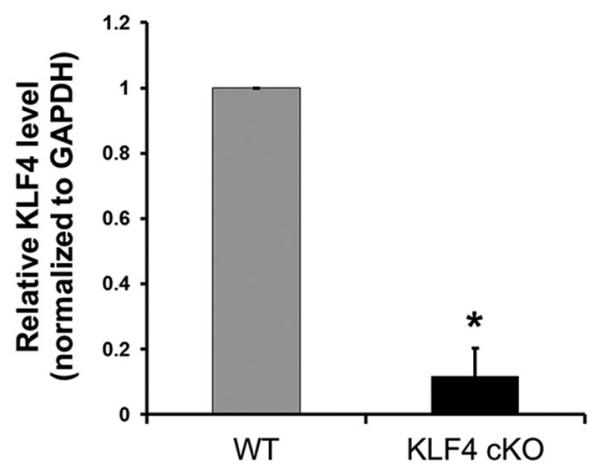

Figure 1. Western blot quantitative analysis of KLF4 protein expression in the retinae of KLF4 cKO and control mice. $\boldsymbol{A}$, Representative images of Western blots against KLF4 and GAPDH as marked. B, Quantification of the relative protein expression normalized to total protein and GAPDH as marked ( $N=3$ for each biological sample; values are reported as the mean \pm SD).

A
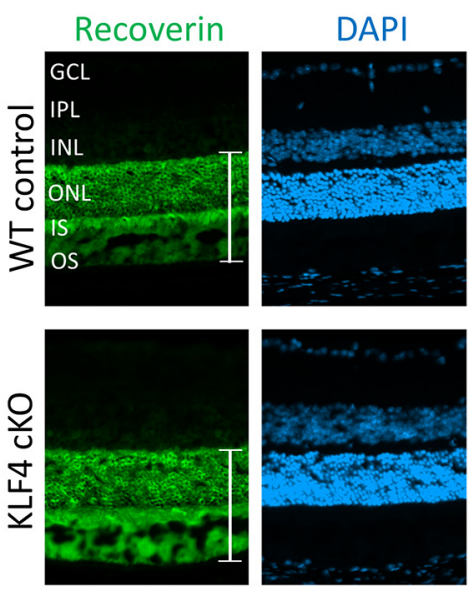

c

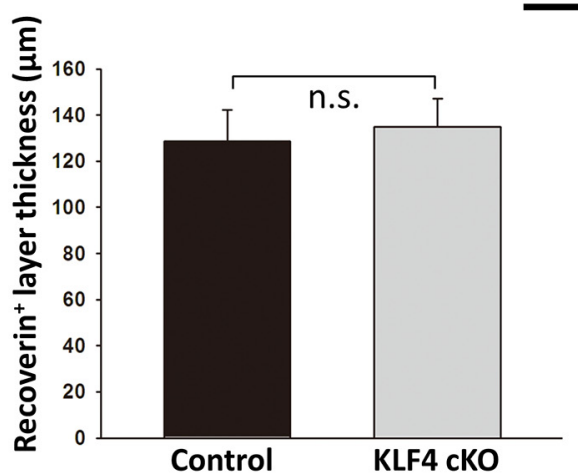

B
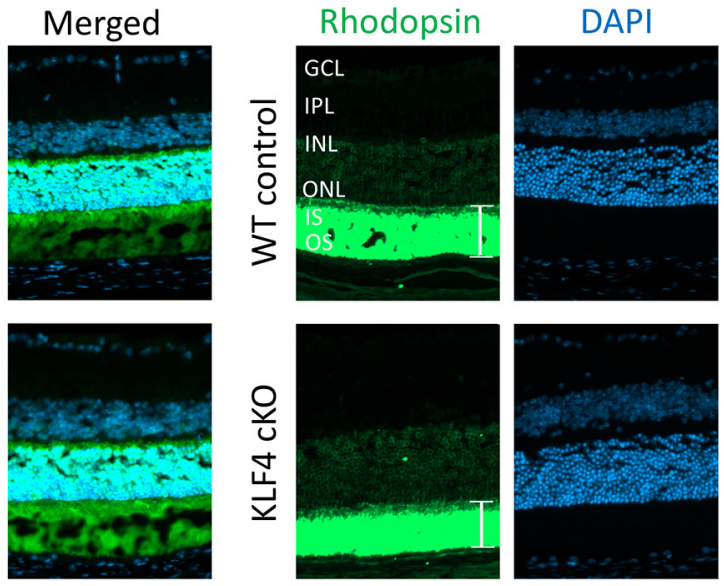

D

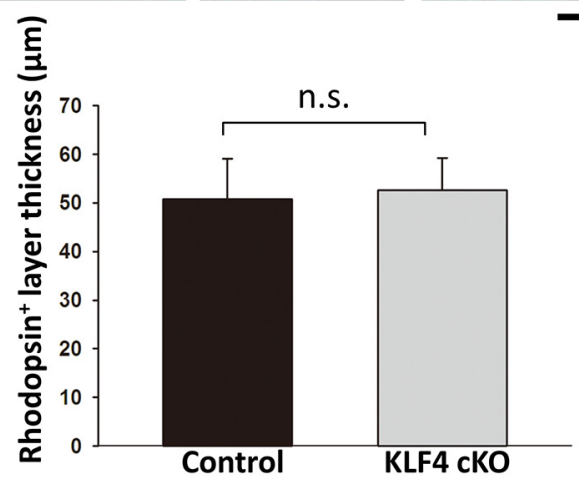

Figure 2. $\boldsymbol{A}, \boldsymbol{B}, \mathrm{KLF} 4$ is not required for photoreceptors or outer segments. Immunofluorescence for recoverin $(\boldsymbol{A})$ and rhodopsin $(\boldsymbol{B}$; green) was counterstained with DAPI for nuclei (blue) in retina cross sections from wild-type control mice (top) and KLF4-cKO mice (bottom). IPL, Inner plexiform layer. $\boldsymbol{C}, \boldsymbol{D}$, The thickness of recoverin ${ }^{+}(\boldsymbol{C})$ and rhodopsin ${ }^{+}(\boldsymbol{D})$ layers (as marked with brackets in $\boldsymbol{A}$ and $\boldsymbol{B}$ ) were measured and found to be nonsignificant (n.S.; values are reported as the mean $\pm \mathrm{SD} ; N=18$ ). Scale bar, $50 \mu \mathrm{m}$.

nology); for photoreceptors and outer segment (OS) layer thickness, recoverin (1:100; EMD Millipore) and rhodopsin (1:100; Pierce/Thermo Scientific); for bipolar cells, rabbit polyclonal anti-protein kinase C- $\alpha$ (PKC- $\alpha$; 1:100; sc-208, Santa Cruz Biotechnology); and for Müller glia rabbit antiglutamine synthetase (GS; 1:100; Sigma-Aldrich). Sec- tions were then rinsed in PBS and incubated with a fluorescent secondary antibody containing 4',6'-diamidino-2-phenylindole dihydrochloride (DAPI; 1:2000; Molecular Probes) for $24 \mathrm{~h}$ at $4^{\circ} \mathrm{C}$ for nuclei staining. The following two secondary antibodies were used in a dilution of 1:500: Alexa Fluor 488 mouse anti-rabbit Texas red 
A
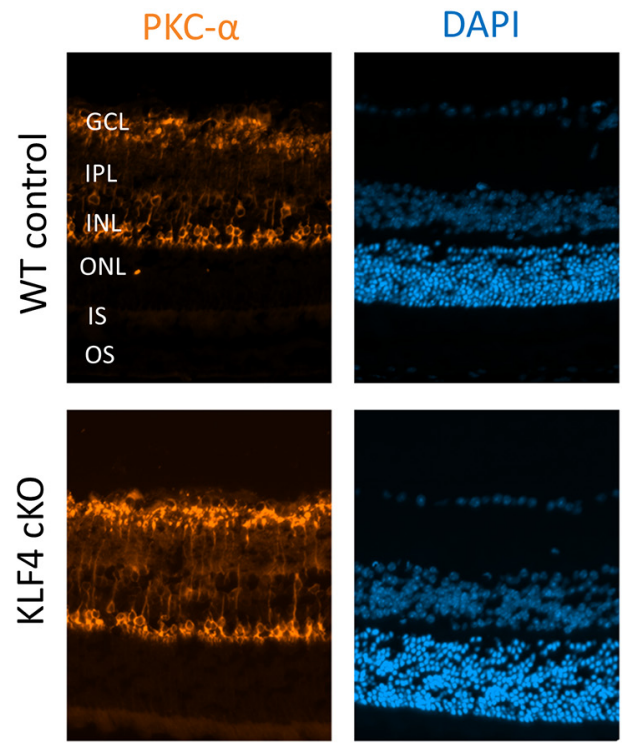

n.s.

\section{Merged}
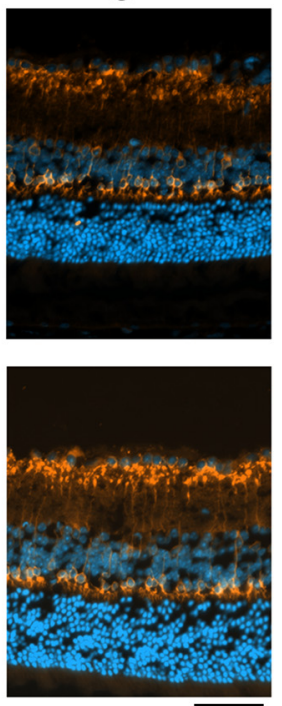

B

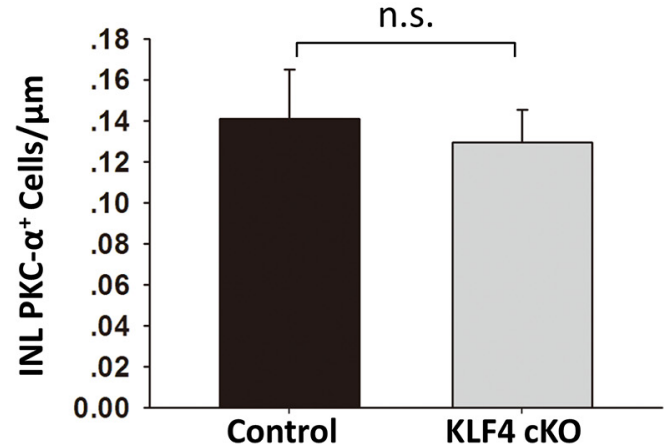

Figure 3. KLF4 does not affect rod bipolar cell numbers. A, Retinal cross sections were immunostained for PKC- $\alpha$ (orange) and counterstained with DAPI (blue). B, PKC- $\alpha^{+}$cells in the INL showed no statistically significant difference between WT and KLF4-cKO groups (n.s.; values are reported as the mean \pm SD; $N=18$ ). Scale bar, $50 \mu \mathrm{m}$.

or Alexa Fluor 546 goat anti-mouse (Molecular Probes). After a subsequent three washes in PBS, these sections were mounted with Vectashield H1000 (Vector Laboratories) and photographed with a Leica microscope.

\section{Morphologic analysis}

Retinal cell counts were measured in cross sections to calculate cell density at a distance of $100-200 \mu \mathrm{m}$ (both sides) from the center of the optic disc. The thickness of axon bundles in the ganglion cell layer (GCL) was quantified by measuring the thickness of the $\beta$ Ill-tubulinimmunostained RGC axons in the retinal nerve fiber layer at $200 \mu \mathrm{m}$ from the center of the optic disc. Thickness of retinal layers containing photoreceptor cells plus outer segments (recoverin ${ }^{+}$layer), and containing rod outer segments (rhodopsin ${ }^{+}$layer) were also measured at 200 $\mu \mathrm{m}$ from the center of the optic disc. All measurements were collected by masked investigators.

\section{Statistical analysis}

Data are presented as the mean \pm SD with $N=18$ replicates per condition; Student's $t$ test (SPSS for Mac version 20.0) was used to test for significance at a $p<0.05$ level.

\section{Results}

\section{Early KLF4 deficiency does not affect photoreceptors into adulthood}

We generated mice with retinas deficient in KLF4 by crossing a floxed KLF4 allele (Moore et al., 2009) with a cre recombinase-expressing line driven by the pan-retinal progenitor expressing marker CHX10 (Jax mice stock \#005105, The Jackson Laboratory). Western blot analysis confirmed that the level of KLF4 protein expression in retinal tissues of

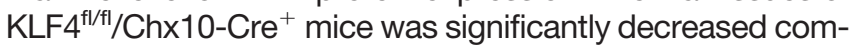
pared with that of the wild-type control mice (Fig. 1). To investigate whether the development of photoreceptors is influenced by retinal expression of KLF4, we examined recoverin on retinal cross sections of conditional knock-out (KLF4-cKO) and WT control mice. Recoverin is a calciumbinding protein that is present in both rod and cone photoreceptors (Polans et al., 1995). Both cKO and WT mice displayed intact photoreceptor cell somata, which showed very high levels of recoverin immunoreactivity throughout the outer nuclear layer (ONL), as well as normal-appearing inner segments (ISs) and OSs (Fig. 2A). We found no significant difference in the thickness of recoverin ${ }^{+}$retinal immunostaining in WT versus KLF4-cKO mice ( $p>0.1$; Fig. $2 C$ ). 
A
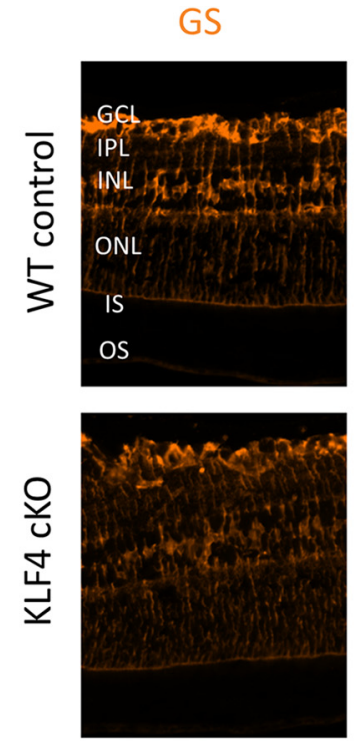

B
DAPI
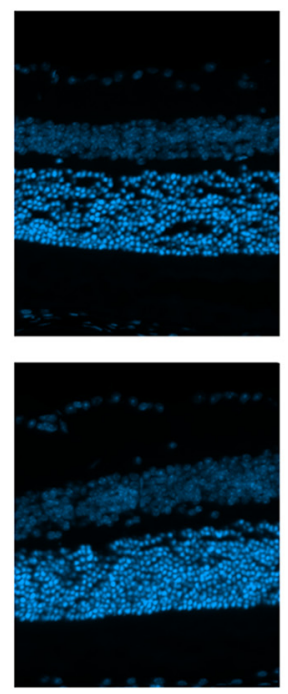

Merged
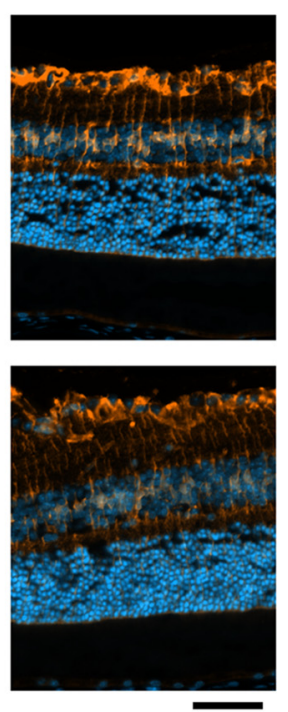

n.s.

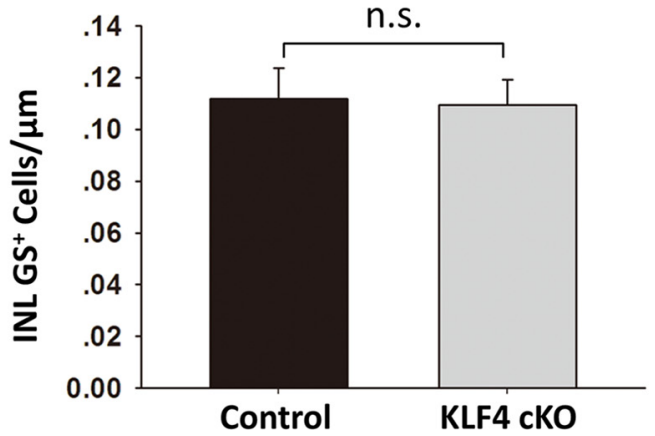

Figure 4. KLF4 does not affect Müller glial cell numbers. $\boldsymbol{A}$, Immunofluorescence staining was performed to detect GS (orange), and cells were counterstained with DAPI (blue). $\boldsymbol{B}$, The GS ${ }^{+}$cells in the INL demonstrated no statistical difference between WT and KLF4-cKO groups (n.s.; values are reported as the mean $\pm \mathrm{SD} ; N=18$ ). Scale bar, $50 \mu \mathrm{m}$.

Rhodopsin is a single-chain integral membrane protein localized to rod outer segment membranes. Similar to recoverin, strong rhodopsin immunoreactivity was found in the photoreceptor outer segments of both WT and KLF4-cKO mice (Fig. 2B), with no significant difference in thickness between the two groups (Fig. 2D). Thus, both IS and OS photoreceptor measures are not dependent on retinal KLF4 expression.

KLF4 is not associated with Müller, amacrine, and bipolar cell survival into adulthood

We next examined other retinal cell markers to determine whether early KLF4 deficiency affects differentiation and survival into adulthood. GS, an enzyme that converts neuron-released glutamate to glutamine, is a specific marker for Müller glia (Fischer and Reh, 2001; Jablonski et al., 2001). Immunostaining for GS demonstrated prominent labeling of Müller cell bodies located in the inner nuclear layer (INL) and their processes, extending to the inner and outer limiting membranes (Fig. $3 A$ ). $\mathrm{GS}^{+}$cell bodies were counted only in the INL, not counting cells in the GCL wrapped by $\mathrm{GS}^{+}$Müller glia end feet. We found no significant difference in Müller cell number between WT and KLF4-CKO mice (Fig. $3 B ; p>0.1$ ).
Using Pax6 as a marker for amacrine cells in the INL as well as the displaced amacrine cells in the ganglion cell layer (Fig. 4A), we found no significant difference between WT and KLF4-CKO mice (Fig. 4B). Using PKC- $\alpha$, which is expressed in cell bodies and processes of ON bipolar cells that mainly connect to rods, we detected PKC- $\alpha$ immunoreactivity in a morphologically distinct population of rod bipolar cells with somata located in the distal row of the inner nuclear layer (Fig. 5A). Again, there was no difference in cell density of bipolar cells in WT versus KLF4-cKO mice ( $p>0.05$; Fig. $5 B$ ). Thus, KLF4 is not required to generate the normal number of bipolar, amacrine, or Müller glial cells in the adult retina.

\section{KLF4 is not associated with RGC differentiation and survival into adulthood}

We previously reported that, using a Thy1-Cre driver to disrupt KLF4 expression in approximately half of RGCs, RGC cell numbers into adulthood were not dependent on the postmitotic expression of KLF4 in RGCs themselves (Moore et al., 2009). Here, we extended those studies to determine whether KLF4 deficiency in progenitors of all retinal cells would affect RGC numbers into adulthood using the Chx10-cre allele. We used the RGC-specific 
A
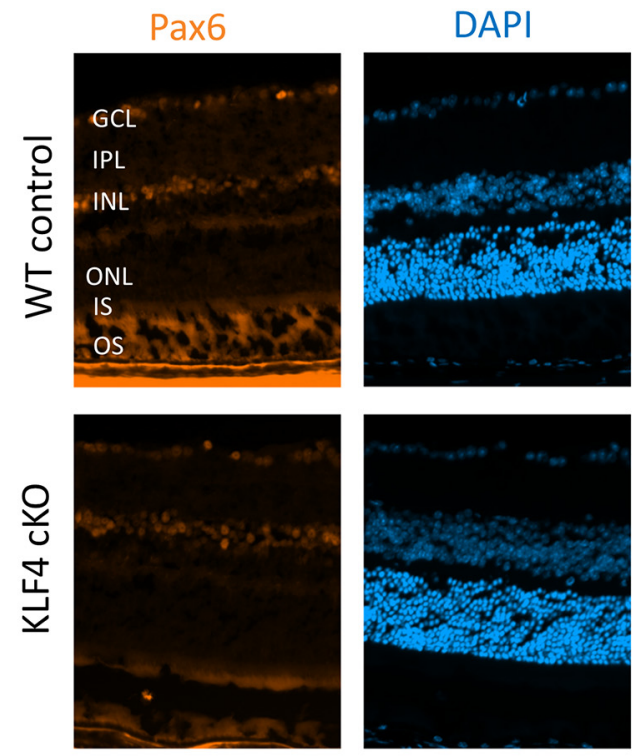

\section{Merged}
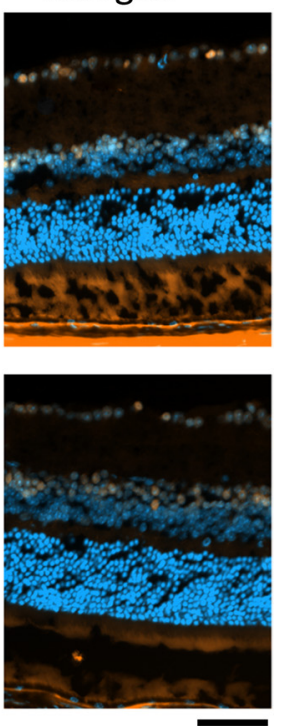

B

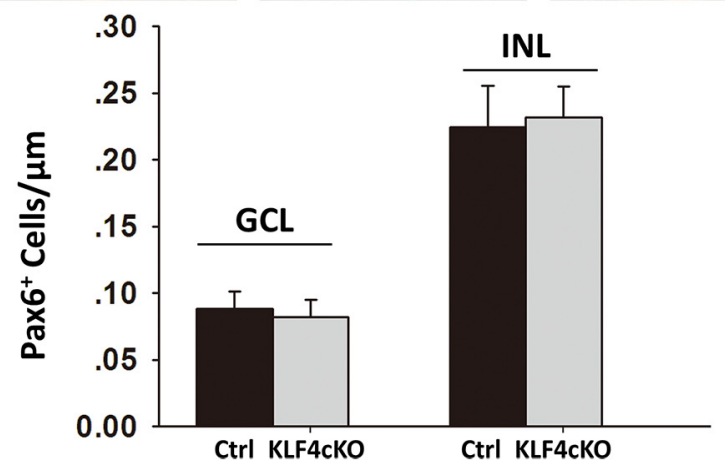

Figure 5. KLF4 is not required for amacrine cell numbers. $\boldsymbol{A}$, Immunofluorescence staining for Pax6 (orange) and counterstaining with DAPI (blue). B, Pax6 ${ }^{+}$cells per unit length showed no statistical difference between WT and KLF4-cKO groups in either the GCL or INL (n.s.; values are reported as the mean $\pm \mathrm{SD} ; N=18$ ). Scale bar, $50 \mu \mathrm{m}$.

marker Brn3a (Fig. 6A; Nadal-Nicolás et al., 2009) and found no significant difference in RGC numbers into adulthood $(p>0.05$; Fig. $6 B$ ). Thus, for all retinal cell types studied, KLF4 deficiency in early retinal progenitor cells does not affect cell numbers or photoreceptor layer thickness into adulthood.

\section{KLF4 is associated with nerve fiber layer thickness}

Finally, because we and others previously found that KLF4 profoundly affects the ability of RGCs to regenerate their axons after optic nerve injury (Moore et al., 2009; Qin et al., 2013), we asked whether KLF4 affects RGC axon growth during normal retinal development in vivo. We used $\beta$ III-tubulin to stain RGC axons in flat-mounted retinas (Fig. 7A) and cross sections (Fig. 7B). Sections that traversed toward the optic nerve were analyzed. Due to the variability of nerve fiber bundles at the optic nerve head and the sparseness of axon bundles in the peripheral retina, we measured axon bundles $200 \mu \mathrm{m}$ away from the optic nerve head to maintain consistency. By analyzing $\beta$ Ill-tubulin, which labeled fasciculated RGC axon bundles in the nerve fiber layer of the retina (Fig. 7B), we found that the thickness of axon bundles in KLF4-cKO mice is significantly increased compared to that of WT mice $(p<0.05$; Fig. 7C). This result supports a model in which KLF4 expression normally suppresses some measure of axon growth in vivo.

\section{Discussion}

During early vertebrate eye development, a regulatory network of transcription factors regulates retinal cell differentiation (Ohsawa and Kageyama, 2008) and survival into adulthood, including Pax6, Six3, Rx, Chx10, Notch, and Notch pathway components (Badea and Nathans, 2011; Mu and Klein, 2004). KLFs including KLF4 regulate differentiation of other cell types throughout the body (Apara and Goldberg, 2014; Moore et al., 2011), and KLF4 is one of a set of four factors capable of reprogramming somatic cells into induced pluripotent stem cells (Hanna et al., 2008; Takahashi et al., 2007; Takahashi and Yamanaka, 2006; Welstead et al., 2008; Yu et al., 2007). KLF4 plays an important role in cell cycle arrest and growth inhibition (Choi et al., 2006; Wei et al., 2005, 2008), and is highly expressed in the postmitotic cells of both the gut and skin (Shields et al., 1996; Zheng et al., 2009). KLF4 has been found to be downregulated in many types of cancers, indicating its possible contribution to cellular hyperproliferation and malignant transformation (Hu et al., 


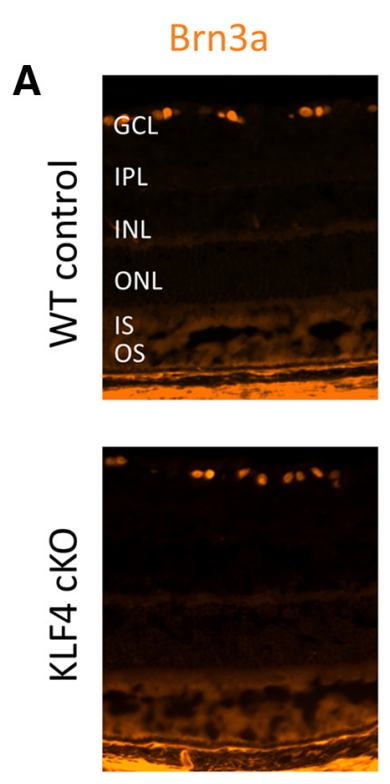

B
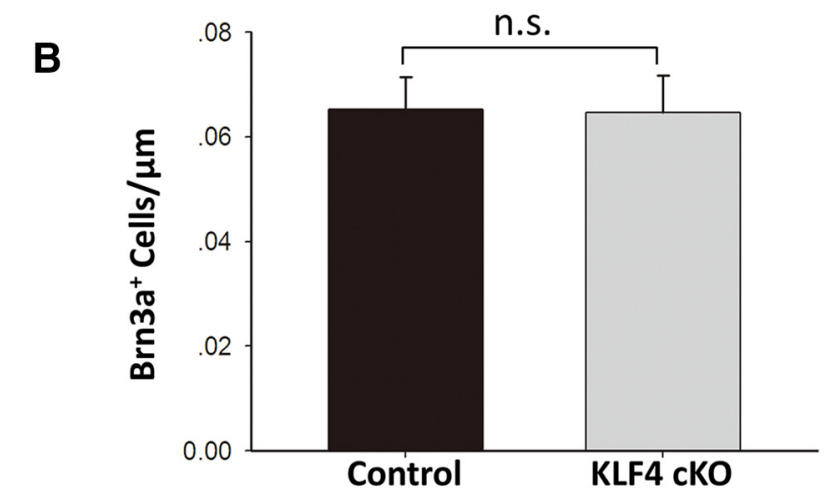

KLF4 cKO
Merged
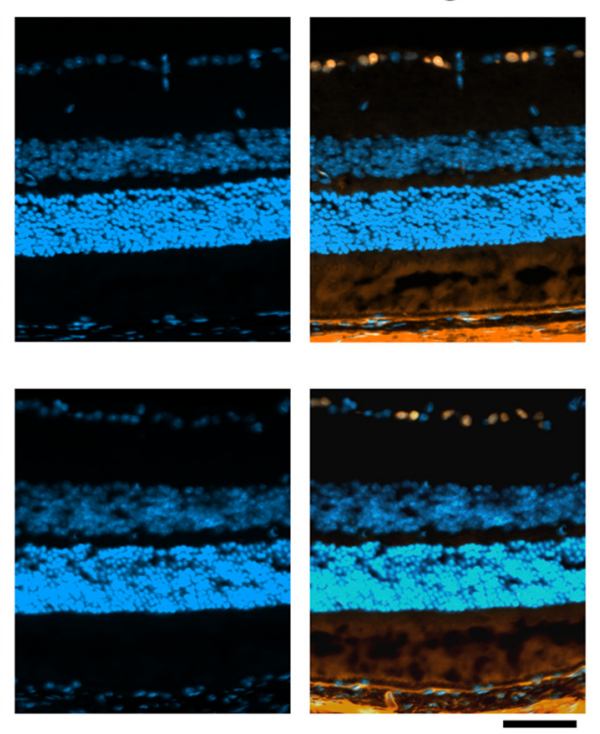

n.s.

Figure 6. KLF4 is not required for RGC cell numbers. $\boldsymbol{A}$, Retinal cross sections were immunostained for Brn3a (orange) and counterstained with DAPI (blue). $\boldsymbol{B}, \mathrm{Brn3a}^{+}$cells showed no statistically significant difference between WT and KLF4-cKO groups (n.s.; values are reported as the mean $\pm \mathrm{SD} ; N=18)$. Scale bar, $50 \mu \mathrm{m}$.

2009; Huang et al., 2005; Wei et al., 2005). However, in other types of primary tumors, such as breast cancer, the expression of KLF4 is upregulated (Foster et al., 2000; Pandya et al., 2004). An exact mechanism by which KLF4 affects negative or positive regulation in cell cycle control remains largely unknown. Progesterone receptor agonists can induce KLF4 expression and inhibit cyclin D1 expression, resulting in the inhibition of cell proliferation in human endometrial epithelial cells (Shimizu et al., 2010). Downregulation of cyclin D1 also controls the proliferation of retinal progenitor cells (Njaine et al., 2010). In addition, p21Cip1 coexpression may determine the tumor suppressor or oncogenic function of KLF4 (Rowland et al., 2005; Rowland and Peeper, 2006). The promoter region of KLF4 contains typical $\mathrm{CpG}$ islands, and, thus, hypermethylation may regulate KLF4 transcription and function in cell cycle control (Song et al., 2013).

In order to characterize the potential roles of KLF4 in retinal neuron differentiation and RGC development, we generated KLF4 conditional knock-out mice driven by Chx10-promoted Cre expression. We performed a Western blot analysis with retinal tissues from cKO and control mice. The results demonstrated the significant reduction $(>80 \%)$ of KLF4 protein in Chx10 Cre-driven KLF4 cKO. The "escape" of a small amount of KLF4 expression in KLF4 cKO retinae may represent either Chx10-derived retinal cells not adequately excising the gene, or cells not derived from retinal progenitors, such as endothelial cells or nerve fiber layer astrocytes; this is a potential limitation of the cKO strategy. Because we did not find any differences in retinal cell numbers in the KLF4-deficient mouse retina, we hypothesize that KLF4 is dispensable for retinal progenitor cell differentiation and/or survival into adulthood. However, it remains plausible that KLF4 plays a role in both differentiation and survival into adulthood, and that alterations in both of these balance out to normal adult retinal cell numbers. The examination of earlier time points in retinal differentiation, for example at late embryonic and early postnatal ages, could assess this question in future experiments. It is also possible that KLF4 contributes to these processes but that other KLFs compensate in the absence of KLF4 (Moore et al., 2011). Furthermore, although we did not detect a difference in total $\mathrm{Pax6}^{+}$amacrine cell numbers in the INL, amacrine 
A

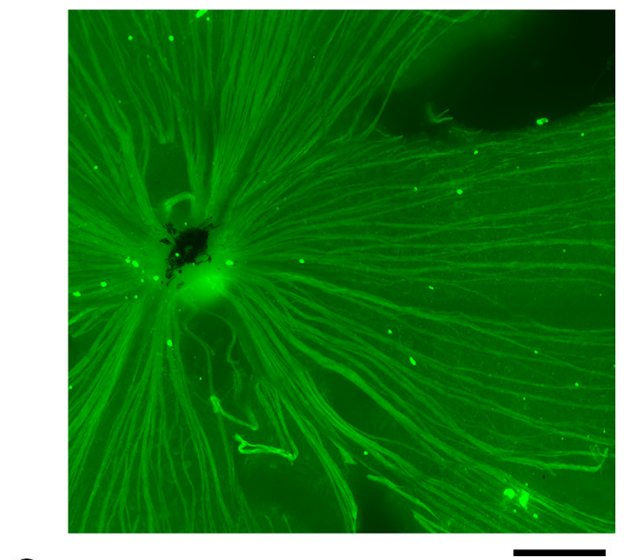

C

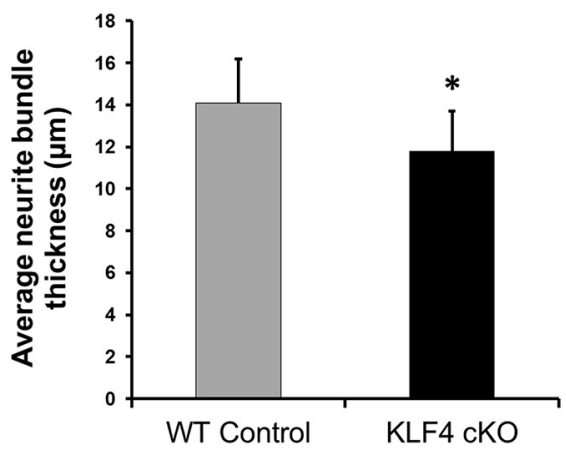

WT Control KLF4 cKO
B

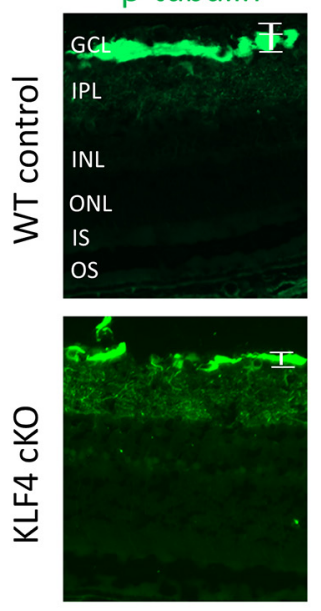

DAPI
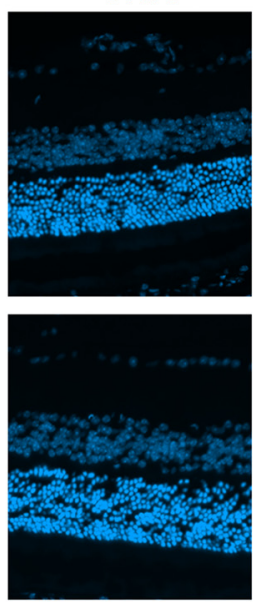

Merged
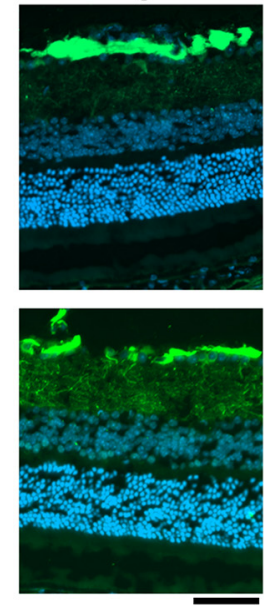

Figure 7. KLF4 deficiency leads to an increase in RGC axon fascicles in the adult retina. $\boldsymbol{A}$, Representative immunofluorescent staining of retinal flat mount. Scale bar, $200 \mu \mathrm{m}$. $\boldsymbol{B}$, Retinal cross sections were immunostained for $\beta$-tubulin (green) and counterstained with DAPI (blue). $\boldsymbol{C}$, The thickness of RGC axon fascicles (brackets in $\boldsymbol{B}$ ) was measured. There was a significant increase in nerve fiber layer axon bundle thickness in KLF4-cKO compared with WT mice $(* p<0.05$; values are reported as the mean $\pm \mathrm{SD} ; N=18)$. Scale bar, $50 \mu \mathrm{m}$.

cell subtype-specific immuno-identification (Kunzevitzky et al., 2013) could reveal changes in the differentiation of specific subpopulations.

RGCs and other CNS neurons in early development demonstrate robust axon growth and regenerative abilities, but their intrinsic capacity for rapid axon growth declines substantially after birth (Goldberg and Barres, 2000; Goldberg et al., 2002). We have recently reported that KLF4 plays a role in regulating intrinsic axon growth ability in RGCs (Moore et al., 2009). Overexpression of KLF4 significantly decreased neurite outgrowth in RGCs, hippocampal and cortical neurons, and RGCs lacking KLF4 showed increased axon growth both in vitro and after optic nerve injury in vivo.

Despite not affecting RGC numbers in the adult animal, in this study, we found that the thickness of RGC axon bundles adjacent to the optic nerve is increased in KLF4cKO mice compared with WT adult mice. We declined to use optical coherence tomography (OCT), a promising technology particularly for longitudinal assessments of retinal layer thickness, as our data revealed subtle changes and OCT does not provide the resolution this available with histology and immunostaining. $\beta$ III-tubulin is a microtubule element expressed exclusively in neurons, and is frequently used to characterize RGCs and their axons in the retina. Other proteins such as neurofila- ment (NF) can mark RGC axons, but NF staining can vary between the axon hillock and the whole axon, depending on phosphorylation and the relative expression of NFheavy, NF-medium, and NF-light chains, which vary in expression in different stages of development and after injury. Studying NF and other axon and synapse proteins would be an interesting area for future research in trying to determine how KLF4 suppresses axon growth in vitro and in vivo.

These data do not differentiate between axon number and axon caliber; an increase in either could explain these findings. Future experiments examining this question at the level of electron microscopy could differentiate between these possibilities, as well as to explore whether there are differences in dendrite elaboration in vivo, for example using single-cell imaging techniques. It would be interesting as well to explore whether these differences in nerve fiber layer thickness detected histologically could be detected in the adult mouse in vivo using noninvasive means such as OCT. Nevertheless, the finding of KLF4 function in suppressing some measure of axon development in vivo is consistent with our and others' previous reports (Moore et al., 2009; Qin et al., 2013) that KLF4 normally acts to inhibit the intrinsic properties of neurite growth. 


\section{References}

Alder JK, Georgantas RW, Hildreth RL, Kaplan IM, Morisot S, Yu XB, McDevitt M, Civin Cl (2008) Kruppel-like factor 4 is essential for inflammatory monocyte differentiation in vivo. J Immunol 180: 5645-5652. Medline

Apara A, Goldberg JL (2014) Molecular mechanisms of the suppression of axon regeneration by KLF transcription factors. Neural Regen Res 9:1418-1421. CrossRef Medline

Badea TC, Nathans J (2011) Morphologies of mouse retinal ganglion cells expressing transcription factors Brn3a, Brn3b, and Brn3c: analysis of wild type and mutant cells using genetically-directed sparse labeling. Vision Res 51:269-279. CrossRef

Bieker, J.J. (2001). Krüppel-like factors: three fingers in many pies. J Biol Chem 276:34355-34358. CrossRef Medline

Carlson CM, Endrizzi BT, Wu JH, Ding XJ, Weinreich MA, Walsh ER, Wani MA, Lingrel JB, Hogquist KA, Jameson SC (2006) Kruppellike factor 2 regulates thymocyte and T-cell migration. Nature 442:299-302. CrossRef Medline

Cepko CL (1999) The roles of intrinsic and extrinsic cues and bHLH genes in the determination of retinal cell fates. Curr Opin Neurobiol 9:37-46. Medline

Cepko CL, Austin CP, Yang X, Alexiades M, Ezzeddine D (1996) Cell fate determination in the vertebrate retina. Proc Natl Acad Sci U S A 93:589-595. Medline

Chiambaretta F, De Graeve F, Turet G, Marceau G, Gain P, Dastugue B, Rigal D, Sapin V (2004) Cell and tissue specific expression of human Krüppel-like transcription factors in human ocular surface. Mol Vis 10:901-909. Medline

Choi BJ, Cho YG, Song JW, Kim CJ, Kim SY, Nam SW, Yoo NJ, Lee JY, Park WS (2006) Altered expression of the KLF4 in colorectal cancers. Pathology, research and practice 202:585-589. CrossRef

Dang DT, Pevsner J, Yang VW (2000) The biology of the mammalian Krüppel-like family of transcription factors. Int J Biochem Cell Biol 32:1103-1121. Medline [Mismatch]

Dorval KM, Bobechko BP, Ahmad KF, Bremner R (2005) Transcriptional activity of the paired-like homeodomain proteins $\mathrm{CHX10}$ and VSX1. J Biol Chem 280:10100-10108. CrossRef Medline

Drissen R, von Lindern M, Kolbus A, Driegen S, Steinlein P, Beug H, Grosveld F, Philipsen S (2005) The erythroid phenotype of EKLFnull mice: defects in hemoglobin metabolism and membrane stability. Mol Cell Biol 25:5205-5214. CrossRef Medline

Fischer AJ, Reh TA (2001) Müller glia are a potential source of neural regeneration in the postnatal chicken retina. Nat Neurosci 4:247252. CrossRef

Foster KW, Frost AR, McKie-Bell P, Lin CY, Engler JA, Grizzle WE, Ruppert JM (2000) Increase of GKLF messenger RNA and protein expression during progression of breast cancer. Cancer research 60:6488-6495. Medline

Ghaleb AM, Nandan MO, Chanchevalap S, Dalton WB, Hisamuddin IM, Yang VW (2005) Krüppel-like factors 4 and 5: the yin and yang regulators of cellular proliferation. Cell Res 15:92-96. CrossRef Medline

Goldberg JL, Barres BA (2000) The relationship between neuronal survival and regeneration. Annu Rev Neurosci 23:579-612. CrossRef Medline

Goldberg JL, Klassen MP, Hua Y, Barres BA (2002) Amacrinesignaled loss of intrinsic axon growth ability by retinal ganglion cells. Science 296:1860-1864. CrossRef Medline

Hanna J, Markoulaki S, Schorderet P, Carey BW, Beard C, Wernig M, Creyghton MP, Steine EJ, Cassady JP, Foreman R, Lengner CJ, Dausman JA, Jaenisch $R$ (2008) Direct reprogramming of terminally differentiated mature $B$ lymphocytes to pluripotency. Cell 133:250-264. CrossRef Medline

Hatakeyama J, Kageyama R (2004) Retinal cell fate determination and bHLH factors. Semin Cell Dev Biol 15:83-89. CrossRef Medline

Hu W, Hofstetter WL, Li H, Zhou Y, He Y, Pataer A, Wang L, Xie K, Swisher SG, Fang B (2009) Putative tumor-suppressive function of Kruppel-like factor 4 in primary lung carcinoma. Clinical cancer research : an official journal of the American Association for Cancer Research 15:5688-5695. Medline

Huang CC, Liu Z, Li X, Bailey SK, Nail CD, Foster KW, Frost AR, Ruppert JM, Lobo-Ruppert SM (2005) KLF4 and PCNA identify stages of tumor initiation in a conditional model of cutaneous squamous epithelial neoplasia. Cancer biology \& therapy 4:14011408. Medline

Jablonski MM, Tombran-Tink J, Mrazek DA, lannaccone A (2001) Pigment epithelium-derived factor supports normal Müller cell development and glutamine synthetase expression after removal of the retinal pigment epithelium. Glia 35:14-25. CrossRef

Kajimura D, Dragomir C, Ramirez F, Laub F (2007) Identification of genes regulated by transcription factor KLF7 in differentiating olfactory sensory neurons. Gene 388:34-42. CrossRef Medline

Kunzevitzky NJ, Willeford KT, Feuer WJ, Almeida MV, Goldberg JL (2013) Amacrine cell subtypes differ in their intrinsic neurite growth capacity. Investigative ophthalmology \& visual science 54:76037613. CrossRef Medline

Livesey FJ, Cepko CL (2001) Vertebrate neural cell-fate determination: lessons from the retina. Nat Rev Neurosci 2:109-118. CrossRef Medline

McConnell BB, Yang VW (2010) Mammalian Krüppel-like factors in health and diseases. Physiol Rev 90:1337-1381. CrossRef Medline

Moore DL, Apara A, Goldberg JL (2011) Krüppel-like transcription factors in the nervous system: novel players in neurite outgrowth and axon regeneration. Mol Cell Neurosci 47:233-243. CrossRef Medline

Moore DL, Blackmore MG, Hu Y, Kaestner KH, Bixby JL, Lemmon VP, Goldberg JL (2009) KLF family members regulate intrinsic axon regeneration ability. Science 326:298-301. CrossRef Medline

Moose HE, Kelly LE, Nekkalapudi S, El-Hodiri HM (2009) Ocular forkhead transcription factors: seeing eye to eye. Int J Dev Biol 53:29-36. CrossRef Medline

Mu X, Klein WH (2004) A gene regulatory hierarchy for retinal ganglion cell specification and differentiation. Semin Cell Dev Biol 15:115-123. CrossRef Medline

Nadal-Nicolás FM, Jiménez-López M, Sobrado-Calvo $P$, NietoLópez L, Cánovas-Martínez I, Salinas-Navarro M, Vidal-Sanz M, Agudo M (2009) Brn3a as a marker of retinal ganglion cells: qualitative and quantitative time course studies in naive and optic nerve-injured retinas. Invest Ophthalmol Vis Sci 50:3860-3868. CrossRef

Njaine B, Martins RA, Santiago MF, Linden R, Silveira MS (2010) Pituitary adenylyl cyclase-activating polypeptide controls the proliferation of retinal progenitor cells through downregulation of cyclin D1. The European journal of neuroscience 32:311-321. CrossRef Medline

Ohsawa R, Kageyama R (2008) Regulation of retinal cell fate specification by multiple transcription factors. Brain Res 1192:90-98. CrossRef Medline

Pandya AY, Talley LI, Frost AR, Fitzgerald TJ, Trivedi V, Chakravarthy M, Chhieng DC, Grizzle WE, Engler JA, Krontiras H, et al. (2004) Nuclear localization of KLF4 is associated with an aggressive phenotype in early-stage breast cancer. Clinical cancer research: an official journal of the American Association for Cancer Research 10:2709-2719. Medline

Polans AS, Witkowska D, Haley TL, Amundson D, Baizer L, Adamus G (1995) Recoverin, a photoreceptor-specific calcium-binding protein, is expressed by the tumor of a patient with cancer-associated retinopathy. Proc Natl Acad Sci U S A 92:9176-9180. CrossRef

Rowland BD, Bernards R, Peeper DS (2005) The KLF4 tumour suppressor is a transcriptional repressor of p53 that acts as a contextdependent oncogene. Nature cell biology 7:1074-1082. Medline

Rowland BD, Peeper DS (2006) KLF4, p21 and context-dependent opposing forces in cancer. Nature reviews Cancer 6:11-23.

Qin S, Zou Y, Zhang CL (2013) Cross-talk between KLF4 and STAT3 regulates axon regeneration. Nat Commun 4:2633. CrossRef Medline

Shields JM, Christy RJ, Yang VW (1996) Identification and characterization of a gene encoding a gut-enriched Kruppel-like factor 
expressed during growth arrest. The Journal of biological chemistry 271:20009-20017. Medline

Shimizu Y, Takeuchi T, Mita S, Notsu T, Mizuguchi K, Kyo S (2010) Kruppel-like factor 4 mediates anti-proliferative effects of progesterone with $\mathrm{G}(0) / \mathrm{G}(1)$ arrest in human endometrial epithelial cells. Journal of endocrinological investigation 33:745-750. CrossRef

Song E, Ma X, Li H, Zhang P, Ni D, Chen W, Gao Y, Fan Y, Pang H, Shi T, et al. (2013) Attenuation of Kruppel-like factor 4 facilitates carcinogenesis by inducing $\mathrm{g} 1 / \mathrm{s}$ phase arrest in clear cell renal cell carcinoma. PLoS One 8:e67758. CrossRef

Swamynathan SK, Katz JP, Kaestner KH, Ashery-Padan R, Crawford MA, Piatigorsky J (2007) Conditional deletion of the mouse Klf4 gene results in corneal epithelial fragility, stromal edema, and loss of conjunctival goblet cells. Mol Cell Biol 27:182-194. CrossRef Medline

Takahashi K, Yamanaka S (2006) Induction of pluripotent stem cells from mouse embryonic and adult fibroblast cultures by defined factors. Cell 126:663-676. CrossRef Medline

Takahashi K, Tanabe K, Ohnuki M, Narita M, Ichisaka T, Tomoda K, Yamanaka S (2007) Induction of pluripotent stem cells from adult human fibroblasts by defined factors. Cell 131:861-872. CrossRef

Turner DL, Cepko CL (1987) A common progenitor for neurons and glia persists in rat retina late in development. Nature 328:131-136. CrossRef Medline

Turner J, Crossley M (1999) Mammalian Krüppel-like transcription factors: more than just a pretty finger. Trends Biochem Sci 24:236240. Medline
Wang L, Yao JC, Wu TT, Huang S, Xie K (2005) Drastic downregulation of Kruppel-like factor 4 expression is critical in human gastric cancer development and progression. Cancer research 65:2746-2754. Medline

Wei D, Gong W, Kanai M, Schlunk C, Wang L, Yao JC, Wu TT, Huang S, Xie K (2005) Drastic down-regulation of Kruppel-like factor 4 expression is critical in human gastric cancer development and progression. Cancer research 65:2746-2754.

Wei D, Kanai M, Jia Z, Le X, Xie K (2008) Kruppel-like factor 4 induces p27Kip1 expression in and suppresses the growth and metastasis of human pancreatic cancer cells. Cancer research 68:4631-4639.

Welstead GG, Brambrink T, Jaenisch R (2008) Generating iPS cells from MEFS through forced expression of Sox-2, Oct-4, c-Myc, and Klf4. J Vis Exp (14):e734.

Yu J, Vodyanik MA, Smuga-Otto K, Antosiewicz-Bourget J, Frane JL, Tian S, Nie J, Jonsdottir GA, Ruotti V, Stewart R, Slukvin II, Thomson JA (2007) Induced pluripotent stem cell lines derived from human somatic cells. Science 318:1917-1920. CrossRef Medline

Yao JH, Zhou JY, Liu QL, Lu DR, Wang L, Qiao XJ, Jia W (2010) Atoh8, a bHLH transcription factor, is required for the development of retina and skeletal muscle in zebrafish. PLoS One 5. CrossRef

Zheng H, Pritchard DM, Yang X, Bennett E, Liu G, Liu C, Ai W (2009) KLF4 gene expression is inhibited by the notch signaling pathway that controls goblet cell differentiation in mouse gastrointestinal tract. American journal of physiology Gastrointestinal and liver physiology 296:G490-G498. Medline 